73. Leoung GS, Chaisson RE, Mills J. Comparison of nosocomial infections due to Staphylococcus aureus and enterococci in a general hospital. Surg G ynecol Obstet 1987;165:339-342.

74. Nichols RL, Muzik AC. Enterococcal infections in surgical patients: the mystery continues. Clin Infect D is 1992;15:72-76.

75. Luginbuhl LM, Rotbart HA, Facklam RR, et al. Neonatal enterococcal sepsis: case-control study and description of an outbreak. Pediatr Infect D is J 1987;6:1022-1030.

76. Rhinehart E, Smith NE, Wennersten C, et al. Rapid dissemina- tion of beta-lactamaseproducing, aminoglycoside-resistant Enterococcus faecalis among patients and staff on an infant-toddler surgical ward. N Engl JMed 1990;323:1814-1818.

77. Zervos MJ, Kauffman CA, Therasse PM, et al. Nosocomial infection by gentamicin-resistant Streptococcus faecalis. Ann Intern M ed 1987;106:687-691.

78. Boyce JM. Should we vigorously try to contain and control MRSA? Infect Control Hosp Epidemiol 1991;12:46-54.

\title{
Peripheral Arterial Lines Found to Be Independent Risk Factor for Coagulase- Negative Staphylococcus epidermidis Bacteremia in Neonates
}

by Gina Pugliese, RN, MS Medical News Editor

Investigators from Emory University School of Medicine and Centers for Disease Control and Prevention recently reported the findings from a study looking at risk factors for nosocomial coagulase-negative Staphylococcus epidermidis (CNSE) bacteremia in very low birthweight (VLBW) infants $(<1,500 \mathrm{~g})$. From February 1986 through January $1987,8(11 \%)$ of 74 VLBW infants in one neonatal intensive care unit (NICU) developed CNSE bacteremia. When case infants with CNSE bloodstream infection were com- pared to uninfected NICU infants, CNSE bacteremic infants had significantly lower birthweight $(P<0.05)$ and longer duration of NICU stay $(P<0.05)$ In multivariate analysis, three risk factors were identified for CNSE bloodstream infection: peripheral arterial line (PAL) for $\geqslant 3$ days $(P<.05)$, central venous line for $\geqslant 3$ days $(P<0.05)$, and prolonged NICU stay $(P<0.05)$. In a nested analysis, matching on birthweight and duration of stay, case infants and controls did not differ significantly in severity of illness; the only significant association found was exposure to a PAL for $\geqslant 3$ days $\left(P=0.02 ; \mathrm{CI}_{95}>1.97\right)$.

These data suggest that PAL for $\geqslant 3$ days is an independent risk factor for CNSE bacteremia in VLBW infants in the NICU. The authors concluded that every attempt should be made to reduce the duration of PAL exposure in these infants.

FROM: McNeil M, Calk T, Butcher $\mathrm{S}$, et al. The peripheral arterial line: an independent risk factor for coagulasenegative staphylococcal epidermidis bacteremia in very low $(<1500 \mathrm{~g})$ birthweight infants. Presented at the 94th General Meeting of the American Society for Microbiology; May 23-27, 1994; Las Vegas, Nevada. Abstract L-8. 